\title{
Pengaruh penyuluhan terhadap pendapatan peternak babi di desa Kiawa dua Timur Kecamatan Kawangkoan Utara
}

\author{
S. J. Hutabarat, A. A. Sajow*, S. O. B. Lombogia, Z. M. Warouw \\ Fakultas Peternakan Universitas Sam Ratulangi Manado 95115 \\ *Korespondensi (corresponding author): adriesajow@unsrat.ac.id
}

\begin{abstract}
ABSTRAK
Penelitian dilaksanakan di desa Kiawa Dua Timur Kecamatan Kawangkoan Kabupaten Minahasa selama satu bulan dari bulan Juni sampai Juli 2020. Penelitian ini bertujuan untuk mengetahui pengaruh penyuluhan dalam peningkatan pendapatan kelompok peternak babi di Kabupaten Minahasa dengan mengambil contoh kasus di desa Kiawa Dua Timur Kecamatan Kawangkoan Utara. Penelitian ini menerapkan penelitian survai yang berbentuk deskriptif tabelaris. Analisis deskriptif digunakan untuk menjelaskan hal-hal yang umum kemudian tabelaris digunakan untuk menjelaskan hubungan antar perubah dalam bentuk tabel. Survai dilakukan dengan metode wawancara dengan panduan kuesioner. Wawancara dilakukan dengan metode wawancara terstruktur dan metode pengumpulan data angket yang dibagikan kepada 30 responden peternak. Hasil analisis data menunjukkan bahwa penyuluhan memiliki pengaruh yang sangat besar dalam peningkatan pendapatan anggota peternak babi di desa Kiawa Dua Timur. Adapun pendapatan peternak sebelum adanya penyuluhan yaitu Rp. 5.833/bulan. Sementara itu, pendapatan peternak setelah adanya penyuluhan adalah sebesar Rp. 880.333/bulan. Usaha ternak babi yang dilakukan oleh kelompok peternak di Desa Kiawa Dua Timur Kecamatan Kawangkoan Utara menguntungkan secara ekonomis dan layak dikembangkan.
\end{abstract}

Kata Kunci : Pengaruh Penyuluhan, Pendapatan Peternak

\begin{abstract}
ABSRTACT
THE EXTENSION EFFECT ON THE INCOME OF PIG FARMERS IN KIAWA DUA TIMUR VILLAGE, KAWANGKOAN UTARA SUB-DISTRICT. The research was conducted in Kiawa Dua Timur village, Kawangkoan district, Minahasa district for one month from June to July 2020. This study aims to determine the effect of counseling on increasing the income of pig farmer groups in Minahasa Regency by taking the case in Kiawa Dua Timur village, Kawangkoan Utara district. This research applies survey research in the form of descriptive tabular. Descriptive analysis is used to explain general things then tabular is used to explain the relationship between variables in tabular form. The survey was conducted by interview method with a questionnaire guide. Interviews were conducted using structured interview methods and questionnaire data collection methods which were distributed to thirty respondents of farmers. The results of study showed that extension services have a very big influence on increasing the income of the members of the pig farmers in the village of Kiawa Dua Timur. The income of farmers before counseling was Rp. 5.833 / month. Meanwhile, the farmer's income after the counseling was Rp.880.333/
\end{abstract}


month. The pig farming business carried out by the farmer group in Kiawa Dua Timur Village, North Kawangkoan District is economically profitable and feasible to develop.

Keywords : Effect of Counseling, Income of Farmer.

\section{PENDAHULUAN}

Ternak babi merupakan salah satu komoditas ternak penghasil daging. Menurut Gusti (2017), Ternak babi tergolong dalam ternak monogastrik dimana memiliki kemampuan dalam mengubah bahan makanan secara efisien apabila ditunjang dengan kualitas ransum yang dikonsumsinya. Keuntungan lain dari beternak babi adalah makanan babi mudah didapat karena babi termasuk hewan omnivora (pemakan segala) serta kotoran babi sangat berguna sebagai pupuk. Jika dilihat dari kelebihan-kelebihannya tersebut maka babi memiliki potensi besar untuk dikembangkan sebagai penghasil daging. Ternak babi di Indonesia telah cukup lama diketahui masyarakat, namun pengetahuan tentang beternak babi yang benar dan produktif belum banyak diterapkan, mengingat kurangnya informasi, akibatnya peternakan babi di Indonesia cenderung masih dilakukan secara tradisional bahkan masih banyak peternakan babi yang dikelola secara sangat sederhana dalam arti belum dikandangkan secara baik, belum diperhatikan pakan, pertumbuhan, perkembangbiakan, maupun kesehatannya. Faktor penyebab rendahnya produktivitas usaha ternak babi adalah sistem pemeliharaan yang jelek, misalnya model kandang yang tidak memenuhi syarat dan sangat berpotensi memicu penyakit. (Hermalinda dan Jacob, 2016)

Dalam mengembangkan ternak babi tentunya tidak terlepas dari peranan Kelompok Tani Ternak dalam mengupayakan ternaknya agar mendapat nilai tambah serta efisien dalam pengelolaannya. Upaya yang perlu dikembangkan dalam membina dan memantapkan kelompok peternak adalah memperkuat kelembagaan ekonomi petani/peternak di pedesaan, untuk itu diperlukan pendekatan yang efektif agar petani/peternak dapat memanfaatkan program pembangunan yang ada, secara berkelanjutan, melalui pertumbuhan rasa memiliki, partisipasi dan pengembangan kreatifitas, disertai dukungan masyarakat lainnya sehingga dapat berkembang dan dikembangkan oleh masyarakat tani disekitarnya (Ediset dan Anas, 2013)

Masalah dalam penyediaan ternak babi adalah tidak sebanding antara kemampuan penawaran (supply) produksi dengan permintaan (demand) daging yang cenderung meningkat setiap tahun. Dampak yang timbul kemudian adalah terjadi penurunan populasi pada beberapa tahun yang lalu merupakan akibat dari makin banyaknya ternak yang dipotong. Salah satu alternatif pemecahan guna mengatasi peningkatan permintaan tersebut adalah melalui budidaya ternak babi. Adanya upaya tersebut akan mendorong peningkatan produksi daging, sehingga disatu sisi secara kuantitas pemotongan dapat ditekan, namun pada sisi lain dimensi kualitas dapat lebih terjamin, dengan perkataan lain usaha budidaya ternak babi yang berhasil akan mampu mengatasi penurunan populasi ternak babi dalam jangka panjang. Budidaya ternak babi pada dasarnya merupakan salah satu upaya intensifikasi di bidang peternakan (Abraham, et al. 2013). Pembinaan kelompok peternak babi melalui penyuluhan merupakan solusi yang tepat untuk menjawab permasalahan kekurangan pemenuhan permintaan kebutuhan daging. Penyuluhan merupakan sebuah intervensi sosial yang melibatkan penggunaan komunikasi informasi secara 
sadar untuk membantu masyarakat membentuk pendapat mereka sendiri dan mengambil keputusan dengan baik. Pembinaan kelompok peternak babi dapat diusahakan dengan cara yang lebih baik dapat memberikan manfaat lebih berarti bagi petani yang mengusahakannya. Oleh karena itu pembangunan peternakan di Kabupaten Minahasa, khususnya pembinaan kelompok peternak babi perlu diarahkan.

Salah satu komotidi peternakan yang potensial di desa tersebut adalah ternak babi. Memelihara ternak babi selain dapat memberi keuntungan, ternak babi dapat juga dipelihara di daerah tropis atau di daerah beriklim sedang. Kegunaan dari ternak babi bermacam-macam, akan tetapi manfaat yang paling dominan adalah menghasilkan daging babi (pork). Daging yang dihasilkan oleh ternak babi dapat memenuhi satu atau dua kebutuhan daging babi yang dapat dikonsumsi oleh peternak dan keluarganya serta dapat dijual sebagai salah satu sumber pendapatan. Ternak babi berdasarkan peta data di dunia menduduki peringkat kedua setelah sapi dalam menyumbang protein hewan. Sedangkan di Indonesia ternak babi merupakan peringkat ketiga setelah ternak sapi dan unggas (Sariubang dan Kaharudin, 2011). Kotoran ternak babi juga dapat digunakan sebagai pupuk dalam perkebunan dan untuk tanaman sehingga dapat berdampak pada pendapatan petani peternak babi. Penyuluhan yang dilakukan selama ini terhadap peternak babi perlu di evaluasi karena itu penelitian ini bertujuan untuk mengetahui pengaruh penyuluhan terhadap pendapatan peternak babi di Kabupaten Minahasa dengan mengambil contoh kasus Desa Kiawa Dua Timur Kecamatan Kawangkoan Utara.

\section{METODE PENELITIAN}

\section{Lokasi dan waktu penelitian}

Penelitian sudah dilaksanakan selama satu bulan mulai bulan Juni sampaibulan Juli 2020 di Desa Kiawa Dua Timur Kecamatan Kawangkoan Utara, Kabupaten Minahasa Propinsi Sulawasi Utara.

\section{Populasi dan sampel}

Populasi dalam penelitian ini adalah kelompok peternak babi yang ada di Desa Kiawa Dua Timur Kecamatan Kawangkoan Utara Kabupaten Minahasa Propinsi Sulawesi Utara. Sampel yang diambil sebanyak 30 peternak babi dalam satu kelompok dengan menggunakan metode purposive random sampling dengan kriteria kelompok peternak yang sudah pernah mengikuti penyuluhan tentang manajemen usaha ternak babi.

\section{Jenis penelitian}

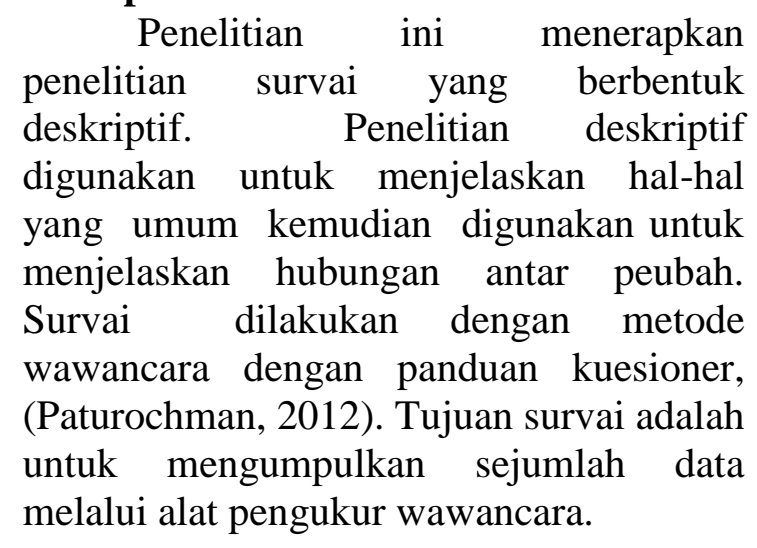

\section{Data dan instrumen}

Penelitian ini menggunakan dua jenis data yang diolah lebih lanjut yaitu data primer dan data sekunder. Data yang dikumpulkan dari para peternak adalah data primer melalui wawancara dengan panduan kuesioner. Sedangkan data sekunder diambil dari bahan rujukan, buku, dan data yang diperoleh dari kantor Kecamatan dan Desa. Data sekunder yang diambil berupa (1) kondisi daerah penelitian, (2) jumlah populasi ternak dan peternak, dan (3) jumlah penyuluh.

Instrumen yang digunakan adalah kuesioner yang mencakup partisipasi peternak dalam perencanaan program 
penyuluhan, pelaksanaan program penyuluhan, dan evaluasi program penyuluhan usaha peternakan babi. Kuisioner dibagi menjadi tiga bagian yang dikategorikan kedalam variabel yaitu (1) variabel karakteristik individu peternak, (2) variabel eksternal peternak dan (3) variabel partisipasi peternak.

\section{Pengumpulan data}

Penelitian dilakukan di Desa Kiawa Dua Timur Kecamatan Kawangkoan Utara Kabupaten Minahasa Propinsi Sulawesi Utara. Data dikumpulkan dengan cara :

1. Menyebarkan kuesioner dengan bantuan Perangkat Desa dan Ketua kelompok untuk diberikan kepada peternak dan diisi sendiri oleh peternak.

2. Pengumpulan data sekunder dari bahan rujukan, buku, dan data yang dapat diperoleh lewat internet.

\section{Analisis data}

Data primer yang terkumpul diolah secara deskriptif dalam bentuk tabel dengan mengacu kepada setiap pertanyaan yang diajukan dalam kuesioner sehingga analisisnya disebut analisis Deskriptif Tabelaris (Sugiyono, 2011).

\section{HASIL DAN PEMBAHASAN}

\section{Karakteristik responden umur peternak}

Dalam kegiatan usaha tani sangat membutuhkan umur yang tergolong produktif dalam melakukan usaha tani. Menurut Hermanto (2011) tingkat umur produktif yaitu 15 - 64 sedangkan umur yang tidak produktif berada dibawah 15 dan diatas 65 tahun. Pada usia sangat produktif diharapkan mampu mencapai puncak produktifitas untuk mengembangkan potensi yang dimiliki oleh setiap peternak dalam melakukan usaha khususnya beternak babi. Hal ini disebabkan untuk bekerja diperlukan kondisi tubuh yang sangat sehat dan pemikiran yang matang.
Untuk lebih jelasnya jumlah responden menurut tingkat umur dapat dilihat pada Tabel 1 .

\section{Pendidikan peternak}

Menurut Room (2017) bahwa tingkat tinggi rendahnya pendidikan petani akan menanamkan sikap yang menuju penggunaan praktek pertanian yang lebih modern. Dalam usaha peternakan faktor pendidikan diharapkan dapat membantu masyarakat dalam upaya peningkatan produksi dan produktifitas ternak yang dipelihara. Tingkat pendidikan formal peternak menunjukkan salah satu faktor penting, khususnya dalam menghadapi teknologi dan keterampilan berusahatani. Tingkat pendidikan juga mempengaruhi pola pikir peternak dalam mengambil keputusan, dimana peternak dengan tingkat pendidikan yang relatif tinggi dapat bertindak lebih dinamis dalam pengolahan usahatani. Secara umum tingkat pendidikan yang tinggi akan meningkatkan produktivitas dan lapangan kerja sehingga berpengaruh pula pada peningkatan pendapatan.

$$
\text { Berdasarkan }
$$

Karakteristik

Responden Berdasarkan Tingkat

Pendidikan di Desa Kiawa Dua Timur Kecamatan Kawangkoan Utara Kabupaten Minahasa, dari keseluruhan peternak responden, ada 10 orang atau 33,33\% yang berpendidikan SD, 9 orang atau $30 \%$ berpendidikan SMP dan 11 orang atau $36,67 \%$ berpendidikan SMA. Hal ini memperlihatkan di Desa Kiawa Dua Timur tingkat pendidikan responden tergolong berpendidikan tinggi, karena masih didominasi oleh pendidikan SMA. Namun peternak responden mempunyai pola pikir yang baik sehingga dapat mengadopsi pengembangan informasi dan inovasi teknologi khususnya teknologi di bidang peternakan dengan cepat. Menurut Sundari et al (2015), menyatakan bahwa keikutsertaan peternak dalam mengikuti pelatihan erat kaitannya dengan usahatani yang mereka lakukan, hal ini mampu 
Tabel 1. Karakteristik Responden berdasarkan Tingkat Umur di Desa Kiawa Dua Timur Kecamatan Kawangkoan Utara Kabupaten Minahasa

\begin{tabular}{lll}
\hline $\begin{array}{l}\text { Umur Petani } \\
\text { (Tahun) }\end{array}$ & $\begin{array}{l}\text { Jumlah } \\
\text { (Jiwa) }\end{array}$ & $\begin{array}{l}\text { Persentase } \\
(\%)\end{array}$ \\
\hline $30-45$ & 16 & 53.33 \\
$>45$ & 14 & 46.67 \\
\hline Total & 30 & 100,00 \\
\hline
\end{tabular}

menambah pengetahuan, keterampilan serta pengalaman mereka untuk melaksanakan kegiatan pengolahan usahatani.

\section{Pengalaman beternak}

Pengalaman beternak responden sangat penting dalam rangka pengelolaan usaha tani ternak. Pengalaman berhubungan dengan keterampilan dan penggunaan teknologi, yang didukung oleh usia peternak yang produktif, maka peternak akan melakukan penerapan teknologi dilahan usahanya. Menurut Hermanto, et, al. (2011), pengalaman beternak kategori sedang yaitu $2-6$ tahun. Sedangkan untuk pengalaman dengan kategori tinggi yaitu $>6$ tahun, ini merupakan modal penting untuk berhasilnya suatu kegiatan usahatani. Berbedanya tingkat pengalaman masingmasing peternak maka akan berbeda pula pola pikir mereka dalam menerapkan inovasi pada kegiatan usahataninya. Penerapan teknologi dan manajemen yang baik akan mempengaruhi perilaku peternak dalam melakukan usahataninya. Semakin lama pengalaman peternak maka resiko kegagalan yang dialaminya akan semakin kecil. Disamping itu akan cepat mengambil keputusan dan menentukan sikap dalam mengatasi masalah yang dihadapinya. Lamanya pengalaman usahatani akan mempengaruhi pula sumber-sumber usahatani lainnya sehingga akan menyebabkan peningkatan pendapatan.

Berdasarkan Karakteristik

Responden Berdasarkan Pengalaman Beternak di Desa Kiawa Dua Timur
Kecamatan Kawangkoan Utara Kabupaten

Minahasa, bahwa dari seluruh peternak

yaitu sebanyak 30 orang, ada 3 orang atau $10 \%$ mempunyai pengalaman beternak antara $2-6$ tahun, sisanya yang berpengalaman beternak $>6$ tahun ada 27 orang atau $90 \%$. Ini berarti bahwa pengalaman beternak $>6$ tahun lebih dominan dari jumlah peternak responden yang ada di Desa Kiawa Dua Timur.

\section{Jumlah tanggungan keluarga}

Jumlah tanggungan keluarga merupakan semua orang yang berada dalam satu keluarga atau satu rumah yang menjadi tanggungan peternak termasuk peternak itu sendiri sebagai kepala keluarga. Kepala keluarga tersebut bertanggung jawab terhadap kelangsungan hidup dan kesehjateraan keluarganya. Banyaknya anggota keluarga sangat berpengaruh terhadap usahatani keluarga bersangkutan, dimana semakin banyak tenaga kerja dalam keluarga maka semakin cepat proses penyesuaian kegiatan usahataninya. Hasil ini sejalan dengan Purwanto dan Tafzatani (2018) yang menyatakan bahwa Jumlah tanggungan akan mempengaruhi tingkat kesejahteraan keluarga apabila memang tidak diimbangi dengan pendapatan yang cukup, sehingga jumlah tanggungan akan terus berbandaing lurus dengan jumlah pendapatan sebagai patokan tingkat kesejahteraan keluarga.

\section{Pengaruh penyuluhan dalam pembinaan Kelompok peternak babi \\ Menurut Chamdi. (2011.) bahwa didalam kegiatan penyuluh diharapkan program-program yang disampaikan hendaknya sesuai dengan permasalahan}


yang dihadapi oleh petani atau sesuai dengan kebutuhannya. Hal ini sejalan dengan Yunasaf et. al. (2011), yang menyatakan bahwa penyuluhan sebagai bagian dari system pendidikan yang sifatnya non formal akan memberikan penguatan kepada para peternak, sehingga pengaruh penyuluhan dalam pembinaan kelompok peternak babi sangat diharapkan untuk merubah dan melakukan proses pembelajaran kepada peternak dalam rangka perubahan perilaku dan peningkatan pendapatan. Dalam hal ini adalah pengetahuan, sikap dan keterampilan yang ditujukan kepada peternak agar dapat beternak lebih baik dan dapat hidup lebih sejahtera (Yulida et. al. 2012). Oleh karena itu, pengaruh penyuluhan dalam membantu dan menolong para peternak tidak terlepas dari dukungan peternak untuk merespon dan mendukung adanya pembinaan kelompok peternak babi. Begitupun pengaruh penyuluhan dan tanggapan balik atau respon peternak untuk meningkatkan produksi hasil ternak dan pendapatan peternak, dimana penyuluhan diharapkan dapat memberikan motivasi dan dorongan kepada peternak agar mau merubah cara hidupnya sesuai dengan perkembangan teknologi peternakan yang lebih maju. Oleh karena itu, peternak mendapatkan manfaat yang besar baik dari segi pengetahuan, wawasan, perubahan perilaku untuk lebih maju dan berkembang dalam menerima inovasi (Astuti, (2011).

Tanggapan Peternak terhadap Penyuluhan dalam Pembinaan Anggota Kelompok Peternak Babi di Desa Kiawa Dua Timur Kecamatan Kawangkoan Utara Kabupaten Minahasa, bahwa responden mengetahui pengaruh penyuluhan dalam pembinaan kelompok peternak babi yang dilakukan oleh penyuluh diperoleh 24 responden yang sangat mengetahui dan 6 responden yang mengetahui. Hal ini menunjukkan bahwa peternak babi mengetahui dengan baik tujuan pembinaan kelompok peternak babi yang dilakukan oleh penyuluh. Indrayani, dan Andri, (2018.) menjelaskan bahwa Peran penyuluh dalam memotivasi peternak dalam beternak babi sangat penting.

Tanggapan Peternak terhadap Pengaruh Penyuluhan dalam Memotivasi Peternak Babi, bahwa untuk pengaruh penyuluhan dalam memotivasi peternak dalam beternak babi untuk kategori skor yaitu $76.67 \%$ yang memilih cukup baik,sementara itu $23.33 \%$ sangat baik. Hal ini menandakan bahwa penyuluhan berpengaruh dalam memotivasi peternak. Sehingga tujuan pembinaan kelompok peternak babi yang dilakukan oleh penyuluh dinas Pertanian Peternakan Dan Perkebunan Kabupaten Minahasa sangat bermanfaat. (Mutmainah, et. al. 2014).

Tanggapan Peternak terhadap Pengaruh Penyuluhan dalam Mempengaruhi Pola Pikir Peternak, bahwa tingkat pendidikan sangat baik terhadap pola pikir dalam beternak babi, hal ini dapat dilihat pada perolehan skor $66,67 \%$ yang menjawab Baik dan 33,33\% yang menjawab Cukup Baik.

Tanggapan Peternak terhadap Pengaruh Penyuluhan dalam Memfasilitasi Pembentukan Kelompok Peternak Babi, bahwa penyuluhan sangat memfasilitasi pembentukan kelompok peternak babi. Hal ini dapat dilihat pada perolehan skor yaitu $70 \%$ yang mengatakan memfasilitasi, $30 \%$ yang mengatakan sangat memfasilitasi. Tanggapan Peternak terhadap Pengaruh Penyuluhan dalam Memberikan Bantuan Bibit Ternak Babi, bahwa 66,67 \% responden menanggapi Baik cara menentukan bibit yang baik sedangkan 33,33 \% menanggapi Cukup Baik. Hal ini sejalan dengan Priyono et al. (2015) bahwa peternak memiliki pesepsi yang sangat baik dengan bantuan peternak berupa sarana produksi.

Tanggapan Peternak terhadap Pengaruh Penyuluhan dalam Memberikan Pelayanan Insiminasi Buatan dan Vaksinasi, bahwa pengaruh penyuluhan sudah memberikan pengetahuan pada 
peternak cara melakukan inseminasi buatan dan vaksinasi pada ternak babi milik anggota kelompok peternak. Hal ini dapat dilihat pada perolehan skor yaitu $100 \%$ yang memilih jawaban Baik.

Hasil yang diperoleh tentang tanggapan atau respon peternak terhadap pembinaan kelompok peternak babi menggambarkan bahwa, kerjasama antara penyuluh sebagai motivator, pendamping dan fasilitator dalam memberikan bantuan, materi dan arahan terjalin kerjasama yang baik dengan peternak sebagai penerima. Program pembinaan kelompok peternak babi yang dikembangkan penyuluh mendapat tanggapan yang baik dari peternak. Oleh karena itu, peternak mendapatkan manfaat yang besar baik dari segi pengetahuan, wawasan, perubahan perilaku untuk lebih maju dan berkembang dalam menerima inovasi khususnya perubahan teknologi peternakan. Hal ini sejalan dengan Astuti (2011) bahwa peternak mendapatkan manfaat yang besar baik dari segi pengetahuan, wawasan, perubahan perilaku untuk lebih maju dan berkembang dalam menerima inovasi.

Manfaat yang juga diperoleh peternak yaitu dapat merubah peningkatan pendapatan yang lebih baik atau meningkat. Hal tersebut bisa terjadi karena pembinaan kelompok peternak babi yang dilakukan oleh penyuluh juga memberikan arahan peningkatan produksi hasil yang dicapai dalam setiap usaha ternak. Indikasi bahwa apabila produksi meningkat berarti pendapatan dan kesejahteraan peternak juga ikut meningkat. Hal ini yang diharapkan dari tujuan pembinaan kelompok peternak babi yang dilakukan oleh penyuluh kepada peternak.

\section{Analisis pendapatan peternak babi}

Menurut Hans Kartikahadi et al. (2012) penghasilan adalah kenaikan manfaat ekonomi selama satu periode akuntansi dalam bentuk pemasukan atau penambahan aset atau penurunan kewajiban yang mengakibatkan kenaikan ekuitas yang tidak berasal dari kontribusi penanam modal. Pendapatan merupakan sumber penghasilan seseorang untuk memenuhi kebutuhan sehari - hari dan sangat penting artinya bagi kelangsungan hidup dan penghidupan seseorang secara langsung mau pun tidak langsung. Besarnya pendapatan adalah penerimaan total dikurangi biaya total untuk jangka waktu satu kali panen. Sebelum pendapatan bersih yang diperoleh, tentu harus diketahui besarnya penerimaan total yaitu total produksi dikalikan dengan harga produksi. Sedangkan biaya total yaitu sejumlah biaya yang dikeluarkan untuk membiayai usahanya yang terdiri atas biaya variabel dan biaya tetap.

Pendapatan peternak sebelum adanya penyuluhan dan belum terbentuknya kelompok peternak belum memberikan keuntungan yang memadai, yaitu hanya sebesar Rp. 5,833 per bulan. Hal ini ditunjukkan dengan nilai $\mathrm{R} / \mathrm{C}$ sebesar 1 yang artinya usaha beternak babi berada pada titik impas. Sedangkan dari hasil kelayakan usaha dengan menggunakan metode analisis $\mathrm{R} / \mathrm{C}$ ratio diperoleh hasil 1,54. $\mathrm{R} / \mathrm{C}$ ratio tersebut menandakan bahwa lebih besar dari satu $(1,54>1)$, berarti usaha beternak babi yang dilakukan oleh kelompok peternak babi memperoleh penerimaan total sebesar 1,54 rupiah untuk tiap biaya total yang dikeluarkan sebesar 1 rupiah, sehingga pendapatan peternak setelah adanya penyuluhan dan sudah terbentuknya kelompok peternak memberikan keuntungan yang cukup signifikan yaitu sebesar Rp. 880.333 per bulan. Hal ini menunjukan peningkatan pendapatan Rp. 875.500 per buan. Usaha beternak babi yang dilakukan oleh kelompok peternak di Desa Kiawa Dua Timur Kecamatan Kawangkoan Utara Kabupaten Minahasa menguntungkan secara ekonomis dan layak diusahakan atau dikembangkan.

\section{KESIMPULAN}




\begin{abstract}
Berdasarkan hasil penelitian maka dapat disimpulkan bahwa pengaruh penyuluhan sangat besar dalam peningkatan pendapatan anggota kelompok peternak babi di Desa Kiawa Dua Timur Kecamatan Kawangkoan Utara Kabupaten Minahasa. Adapun pendapatan peternak sebelum adanya penyuluh yaitu Rp. 5.833 per bulan. Sementara itu, pendapatan peternak setelah adanya penyuluh adalah sebesar Rp. 880,333 per bulan. Ini artinya pendapatan peternak meningkat sebesar Rp.875.500 per bulan.
\end{abstract}

\section{DAFTAR PUSTAKA}

Abraham D.R, M.A.V. Manese, dan L.W.Sondakh. 2013. Analisis keuntungan integrasi usaha ternak babi dengan ikan mujair di Kecamatan Sonder Kabupaten Minahasa. Zootek 31(1): 1-10.

Anwas,O.M. 2013. Pengaruh pendidikan formal pelatihan dan intensitas pertemuan terhadap kompetensi penyuluh pertanian. Jurnal Pendidikan dan Kebudayaan.19(1):50-62.

Astuti, M. 2011. Analisa Keuntungan Sistem Pertanian Terpadu Berbasis Holtikultura Pada Kelompok Tani Bumi Harapan Di Nagari Koto Tinggi Kecamatan Baso Kabupaten Agam [Skripsi]. Padang: Fakultas Pertanian Universitas Andalas

Chamdi AN. 2011. Jurnal Karakteristik Sumberdaya Genetik Ternak Babi Bali (Bos-bibos banteng) dan alternatif pola konservasinya. Biodiversitas. 6:70-75.

Dali. I., F S. Oley, A.K.Rintjap dan J M.Tumewu. 2017. Hubungan kinerja penyuluh pertanian lapangan dengan keberhasilan peternak sapi potong di Kecamatan Kwandang Kabupaten Gorontalo Utara. Jurnal Zootek Vol 37(2):403-414.

Ditjen Peternakan. 2010. Rencana Strategis Sub Sektor Peternakan
Indonesia Tahun 2010-2014. Departemen Pertanian RI, Jakarta

Ediset dan A. Anas. 2013. Peranan penyuluh dalam penerapan paket teknologi pada usaha peternakan kerbau (Studi Kasus Pada Kelompok Ternak "Kerbau Antrada" Kecamatan Koto Baru Kabupaten Dharmasraya). Jurnal Peternakan Indonesia Vol 15(1): 17-25.

Gusti Ayu Mayani, Kristina Dewi. 2017. Materi Ilmu Ternak Babi. Fakultas Peternakan Universitas Udayana. $1-62$

Kartikahadi, H., U. Rosita M.S Sinaga, S V. Siregar. 2012. Akuntansi Keuangan berdasarkan SAK berbasis IFRS. Jakarta : Salemba

Hermanto K. S, dan D. Swastika. 2011. Penguatan kelompok tani : langkah awal peningkatan kesejahtraan petani. Jurnal Analisis Kebijakan Pertanian. $9:$ 371-390.

Hermilinda Parera dan Jois M. Jacob. 2016. Peningkatan manajemen kesehatan babi dan pertanian terpadu di kelompok mawar dan kelompok Lorosae. Jurnal Politeknik Pertanian . 1(1): 1-13.

Harinta, Y.W., 2011. Adopsi inovasi pertanian di kalangan petani di Kecamatan Gatak Kabupaten Sukoharjo. Jurnal Agribisnis 15(2):164-174

Ikbal, M. 2014. Peranan Kelompok Tani dalam Meningkatkan Pendapatan Petani Padi Sawah di Desa Margamulya Kecamatan Bungku Barat Kabupaten Morowali. e-J. Agrotekbis, 15(2):505-509.

Kojo RE, Panelewen VVJ, Manese MAV . 2014. Efisiensi penggunaan input pakan dan keuntungan pada usaha ternak babi di Kecamatan Tareran Kabupaten Minahasa Selatan. Zootek 31(1): 1-10. 
Mutmainah, R., dan Sumardjo. 2014. Peran Kepemimpinan kelompok tani dan efektivitas pemberdayaan petani. Jurnal Sosiologi Pedesaan, 19(1):182-199.

Paturochman. M. 2012. Penentuan Jumlah dan Teknik Pengambilan Sampel. Unpad Press, Bandung. 55-56

Priyono, M.I., D. Shiddieqy, Widiyantono dan Zulfanita. 2015. Hubungan kausal antara tingkat penguasaan teknologi, dukungan kelembagaan dan peran penyuluhan terhadap adopsi integrasi ternak. Jurnal Informatika Pertanian. 24(2):141148.

Purwanto, A dan B. M. Tafzatani, 2018. Pengaruh jumlah tanggungan terhadap tingkat kesejahteraan ekonomi keluarga pekerja P3L Universitas Padjajaran. 1(2): 33-43.

Rahmawati, I.R, Muksin dan Rizal. 2015. Peran dan kinerja penyuluh pertanian dalam memberdayakan peternaka ayam petelur di Kabupaten Jember. Jurnal Ilmiah Inovasi . 15 (3): 56-63.

Room. M.J.V. 2017. Adopsi inovasi PTT padi sawah di Kabupaten Maluku Tengah Provinsi Maluku, Prosiding Seminar Nasional.

Sapar, A., P.S. Jahi, Asngari, Amiruddin dan I.G.P. Purnaba. 2012. Kinerja penyuluh pertanian dan dampaknya pada kompetensi petani kakao di empat wilayah Sulawesi Selatan. Jurnal Penyuluhan.8(1):29-41.

Sariubang M, Kaharuddin. 2011. Analisis ekonomi pemeliharaan ternak babi secara tradisional di Kabupaten Toraja, Sulawesi Selatan. Jurnal Agrisistem 7(2): 116-122.

Sugiyono, 2013, Metodelogi Penelitian Kuantitatif, Kualitatif Dan R\&D. (Bandung: ALFABETA)

Sundari., A.A Hamid, Yusra dan Nurliza. 2015. Peran penyuluh pertanian terhadap peningkatan produksi usahatani di Kabupaten Pontianak. Jurnal Social Economic of Agriculture 4(1): 26-31.

Unang Yunasaf dan Didin S. Taspirin. 2011. Peran Penyuluh dalam Proses Pembelajaran Peternak Sapi Perah di KSU Tandangsari Sumedang. Jurnal Ilmu Ternak. 20 (2): 98-103

Utami, S.N dan S.K. Sita. 2018. Peran Komunikasi penyuluh lapangan dalam pembangunan agribisnis ternak itik di Kabupaten Brebes. Jurnal Peternakan Indonesia 20 (3): 1601655-140.

Yulida. R. Kausar dan L. Marjelita. 2012. Dampak kegiatan penyuluhan terhadap perubahan perilaku petani sayuran di Kota Pekanbaru. Indonesian. Journal of Agricultural Economics.3(1):37-5 
